\title{
Growth and Productivity of Different Potato Cultivars
}

\author{
Bulti Merga $^{1} \&$ Nigussie Dechassa ${ }^{1}$ \\ ${ }^{1}$ School of Plant Sciences, Haramaya University, Ethiopia \\ Correspondence: Bulti Merga, School of Plant Sciences, Haramaya University, Ethiopia. E-mail: \\ bultimerga@gmail.com \\ Received: November 20, 2018 \\ Accepted: December 27, 2018 Online Published: February 15, 2019 \\ doi:10.5539/jas.v11n3p528 \\ URL: https://doi.org/10.5539/jas.v11n3p528
}

\begin{abstract}
During the experimental years of 2017 and 2018 eight potato cultivars were evaluated for their growth traits and productivity in tuber yield. The potato cultivars used in these experimental seasons were; Bubu (as a standard check), Chiro, Gebisa, Belete, Gudene, Badasa Jarso and Dedafa. The first six consecutive potatoes are improved cultivars which were released by Ethiopian research institute and University while the last two potatoes were collected from farmers and cultivated as local (native) cultivars. The objective of this study was to compare the growth and productivity potato cultivars grown at eastern regions of Ethiopia. The results revealed that performance of improved potato cultivars were high in both evaluated yield related traits and average tuber yield. The performances of evaluated potatoes were not similar among cultivars and within cultivar throughout experimental seasons. The experimental design was a randomized block design in three replications. The field management; seed tuber selection, land preparation, planting, fertilizer application method and amount, ridging, weeding, cultivation, harvesting, data collection method and collected data analysis has been carried out for all potato cultivars in similar manner. Potato tubers from four middle rows were analyzed for parameters such as tuber yield, tuber number, marketable and total tuber yield. The highest tuber yield was revealed with cultivar Bubu $\left(39.4 \mathrm{t} \mathrm{ha}^{-1}\right)$ while the lowest with Jarso $\left(20.89 \mathrm{t} \mathrm{ha}^{-1}\right)$. The highest tuber number was showed with cultivar Badasa $\left(12.73\right.$ plant $\left.^{-1}\right)$ and the lowest with Belete $\left(7\right.$ plant $\left.^{-1}\right)$. Hence, there were no correlation between average tuber yield and number.
\end{abstract}

Keywords: Solanum tuberosum, tuber yield, tuber number

\section{Introduction}

With the increase in Ethiopia's population and decrease in arable land, food security issues have become more prominent. Potato (Solanum tuberosum L.) is one of the most widely grown food crops after the three cereals viz., maize, rice and wheat (Vleeshouwers et al., 2011). Potato is an important food and cash crop in Eastern and Central Africa, playing a major role in national food security and nutrition, poverty alleviation and income generation, and; provides employment in the production, processing and marketing sub-sectors (Lung'aho et al., 2007). In Ethiopia, potato crop is being cultivated regularly each year on the $69,610.81$ area in hectares $9,689,696.44$, production in quintals 139.20 , yield (qt/ha) during 2017/18 (FDRE CSA. 2017/18). In the past, in Eastern Ethiopia, potato was cultivated in small gardens, but right now this crop is being cultivated on a large scale.

Ethiopia is endowed with suitable climatic and edaphic conditions for high quality potato production. Moreover, many improved cultivars with on-farm yield potential of 19-38 tonnes ha ${ }^{-1}$ were developed by research centres and demonstrated to farmers for production (Gebremedhin et al., 2008a). The low hectarage and yield of potato in Ethiopia are attributed to many factors. The major ones are lack of well adapted and high yielding cultivars, availability and high cost of seed tubers, inappropriate agronomic practices, and lack of marketing and suitable post-harvest management facilities as well as insect pests and disease (Gildemacher et al., 2009a).

The production of improved potato cultivar is low while many potato growers are cultivating local cultivars to sustain their livelihood and profit generation from this crop. However, currently some potato growers are getting awareness through training, demonstrations and farmers participatory research from different Institute of Agricultural Research and Non-governmental seed sectors to produce improved cultivars. Farmers that cultivate local varieties are reported to get yields equivalent to those that cultivate improved varieties. This might be due to good farm management practices, which may be stimulated by the prospect of export market (Adane et al., 
2010). The comparative performances of the potato cultivars released Ethiopian Agricultural Research Centers and Universities are not elucidated. In addition, little scientific information has been documented on these potato cultivars. For these reasons, there is a need to collect, characterize, evaluate and even promote local potato cultivars or genotypes before they become out of production (Balkaya \& Ergun, 2008). Therefore, this study was initiated with the objective of comparing the growth and productivity of improved and local (native) potato cultivars.

\section{Materials and Method}

The number of potato cultivars used for evaluation during experimental years of 2017 and 2018 at Haramaya University Raaree research farm of Ethiopia were eight; Bubu (as a check), Chiro, Gebisa, Jarso, Belete, Gudene, Badasa and Dedafa. The experimental design was a randomized block design in three replications. Each potato cultivars were planted in six rows $4 \mathrm{~m}$ long, with $0.75 \mathrm{~m}$ space between rows and $0.30 \mathrm{~m}$ between tubers in a row. The experimental units were distant $1.0 \mathrm{~m}$ among each other. Previous crop in both years was wheat and corn in 2017 and 2018, respectively. Potato seed tuber planting was done in manual method on the first week of April for both years of experimental period. Potato yield of four inner rows was analyzed for all cultivars. In both years, each experimental plot received the following amount of fertilizers: $100 \mathrm{~kg} \mathrm{ha}^{-1}$ Urea $\left(\mathrm{CO}\left[\mathrm{NH}_{2}\right]_{2}\right)$ $(46 \% \mathrm{~N})$ and $150 \mathrm{~kg} \mathrm{ha}^{-1}$ TSP (Triple-Super Phosphate), which constitutes about $46 \% \mathrm{P}_{2} \mathrm{O}_{5}$, were used as a source of inorganic fertilizer in basal application method. Urea was applied two times; $1 / 2$ during planting, and $1 / 2$ at stage of flower initiation while TSP was applied during planting as a full doze. The study was conducted in field (Stolon number, potato tuber number, and tuber yield). All valuations were completed in potato tubers collected from four middle rows from experimental plots. The data were subjected to analysis of variance (ANOVA) of RCBD in factorial arrangements for each location using the general linear model of Genstat $16^{\text {th }}$ edition updated version. Treatment means that exhibited significant differences was separated using Fisher's unprotected least significant difference test at $5 \%$ level of significance.

The duration of vegetative time (maturity) is a potato cultivars characteristic affected by planting season, climatic condition and implemented cultivation rehearses. There are considerable differences with respect to the vegetation time, depending on the cultivars peculiarities. In the ecological circumstance of Haramaya, the vegetation time of potato cultivars ranges from 90 to 130 days, as can be revealed in Table 1 .

Table 1. Potato cultivars name and their growth characteristics

\begin{tabular}{llll}
\hline No. & Variety & Collection $^{\mathrm{a}}$ & Maturity and other characteristics $^{\mathrm{b}}$ \\
\hline 1 & Bubu & Improved & Medium late maturing, high yielding, late blight tolerant \\
2 & Belete & Improved & Early maturing, high yielding, late blight tolerant \\
3 & Gudanie & Improved & Early maturing, high yielding, late blight tolerant \\
4 & Gabbisa & Improved & Early maturing, high yielding, late blight tolerant \\
5 & Badhasa & Improved & Medium early, early flowering, russet tubers \\
6 & Chiro & Improved & Early maturing, round tubers with deep eyes \\
7 & Dedafa & Native & Medium early, late flowering, market desired tuber size \\
8 & Jarso & Native & Medium early, early flowering, round purple tubers \\
\hline
\end{tabular}

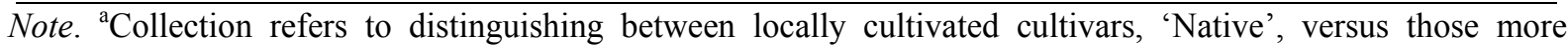
recently introduced varieties, 'Improved'.

${ }^{\mathrm{b}}$ Cultivars were grouped into six maturity classes; very early $(<90$ days), early (90-100), medium early (101-110), medium late (111-120), late (121-130) and very late ( $>130$ days) based on Belmehr season production.

Source: MoA, 2013 and 2012. 
Table 2. Name, accession code, year of release, and yield potential under researchers' and farmers' management practices, maintainer center of potato varieties and recommended growing altitude

\begin{tabular}{llllllll}
\hline No. & Variety or genotype & Accession code & Year of release & Yield $\left(\mathrm{t} \mathrm{ha}^{-1}\right)$ & Breeding Center & $\begin{array}{l}\text { Recommended Altitude } \\
(\text { meters above sea level })\end{array}$ \\
\hline 1 & Bubu & CIP-384321-3 & 2011 & $39-42$ & $35-39$ & Haramaya University & $1700-2000$ \\
2 & Belete & CIP-393371.58 & 2009 & 47.2 & $28-33.8$ & Holeta Research Center & $1600-2800$ \\
3 & Gudanie & CIP-386423.13 & 2006 & 29.0 & 21 & Holeta Research Center & $1600-2800$ \\
4 & Gabbisa & CIP-3870-96-11 & 2005 & 40.0 & 31 & Haramaya University & $1700-2000$ \\
5 & Badhasa & AL-114 & 2001 & 40.6 & - & Haramaya University & $2400-3350$ \\
6 & Chiro & AL-111 & 1998 & $32-40$ & $25-35$ & Haramaya University & $2700-3200$ \\
7 & Dedafa & Local cultivar & - & - & & - & East Hararghe \\
8 & Jarso & Local cultivar & - & - & & - & East Hararghe \\
\hline
\end{tabular}

Note. Varieties with initial AL are the old potato genotypes (before 1987) maintained by Haramaya University; varieties with initial CIP are materials introduced from International Center for Potato, Peru after the first release of potato varieties in the country (1987) and varieties with KP initial are introductions other than from CIP.

Source: MoA, 2013 and 2012.

\section{Results}

\subsection{Stolon Number Plant ${ }^{-1}$}

Stolon number was varied significantly among the potato cultivarss. The highest stolon number plant ${ }^{-1}$ was found from Bubu cultivar (22.065) and Badasa cultivar (21.535) potato cultivars while the lowest stolon number was found from Jarso (15.535) and dedafa cultivar (16.235).

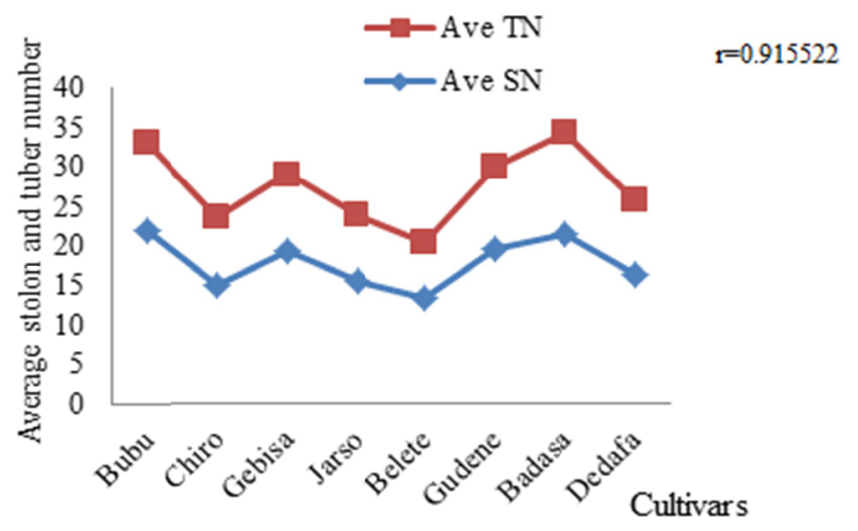

Figure 1. The correlation between average stolon number (Ave SN), and average tuber number (Ave TN), during 2017 and 2018 potato growing season

\subsection{Number of Tubers Plant ${ }^{-1}$}

There were significant differences in the number of tubers per plant among varieties (Table 3). Badasa, generating the greatest number of tubers plant ${ }^{-1}$ (12.7315), was not significantly different from Bubu (10.8 tubers plant ${ }^{-1}$ ), but was significantly different from all the other varieties: Chiro (8.535), Gebisa (9.8985), Jarso (8.3765), Belete (6.985), Gudene (10.4185) and Dedafa (9.58) number of tubers plant ${ }^{-1}$ (Table 3). 
Table 3. Comparison of eight potato cultivars on yield related traits

\begin{tabular}{|c|c|c|c|c|c|c|}
\hline \multirow{2}{*}{ Treatment } & \multicolumn{3}{|c|}{ Stolon number plant ${ }^{-1}$} & \multicolumn{3}{|c|}{ Tuber number plant $^{-1}$} \\
\hline & 2017 & 2018 & Average & 2017 & 2018 & Average \\
\hline Bubu & $29.80^{\mathrm{a}}$ & $14.33^{\text {c-e }}$ & $22.065^{\mathrm{a}}$ & $16.67^{\mathrm{ab}}$ & $4.93^{\mathrm{bc}}$ & $10.8^{\mathrm{ab}}$ \\
\hline Chiro & $15.67^{\mathrm{de}}$ & $14.13^{\mathrm{c}-\mathrm{e}}$ & $14.9^{\mathrm{cd}}$ & $12.47^{\mathrm{c}-\mathrm{e}}$ & $4.6^{\mathrm{c}}$ & $8.535^{\mathrm{cd}}$ \\
\hline Gebisa & $22.33^{\mathrm{b}-\mathrm{d}}$ & $16^{\mathrm{b}-\mathrm{e}}$ & $19.165^{\mathrm{ab}}$ & $14.33^{\mathrm{b}-\mathrm{d}}$ & $5.467^{\mathrm{bc}}$ & $9.8985^{\mathrm{bc}}$ \\
\hline Jarso & $15.67^{\mathrm{de}}$ & $15.40^{\mathrm{b}-\mathrm{e}}$ & $15.535^{\mathrm{b}-\mathrm{d}}$ & $11.87^{\mathrm{c}-\mathrm{e}}$ & $4.883^{\mathrm{bc}}$ & $8.3765^{\mathrm{cd}}$ \\
\hline Belete & $15.27^{\mathrm{e}}$ & $11.47^{\mathrm{e}}$ & $13.37^{\mathrm{d}}$ & $10.27^{\mathrm{e}}$ & $3.7^{\mathrm{c}}$ & $6.985^{\mathrm{d}}$ \\
\hline Gudene & $21.47^{\mathrm{b}-\mathrm{e}}$ & $17.47^{\mathrm{b}-\mathrm{d}}$ & $19.47^{\mathrm{ab}}$ & $14.47^{\mathrm{b}-\mathrm{d}}$ & $6.367^{\mathrm{a}-\mathrm{c}}$ & $10.4185^{\mathrm{bc}}$ \\
\hline Badasa & $25.20^{\mathrm{a}-\mathrm{c}}$ & $17.87^{\mathrm{a}-\mathrm{d}}$ & $21.535^{\mathrm{a}}$ & $20.53^{\mathrm{a}}$ & $4.933^{\mathrm{bc}}$ & $12.7315^{\mathrm{a}}$ \\
\hline Dedafa & $19.07^{\mathrm{c}-\mathrm{e}}$ & $13.4^{\mathrm{c}-\mathrm{e}}$ & $16.235^{\mathrm{b}-\mathrm{d}}$ & $14^{\mathrm{b}-\mathrm{e}}$ & $5.16^{\mathrm{bc}}$ & $9.58^{\mathrm{bc}}$ \\
\hline $\operatorname{LSD}(5 \%)$ & 6.797 & 5.856 & 4.080 & 4.024 & 2.69 & 2.209 \\
\hline $\mathrm{CV}$ & 19.7 & 21.9 & 13.3 & 16.9 & 28.3 & 13.3 \\
\hline $\mathrm{T}$ test & * & $*$ & * & *. & $*$ & $*$ \\
\hline
\end{tabular}

Note. Means with the same letter(s) within a column are not significantly different at $5 \%$ level of significance. $\mathrm{NS}=$ non-significant difference, $\operatorname{LSD}(5 \%)=$ Least significant difference at $\mathrm{P}=0.05$, and $\mathrm{CV}(\%)=$ Coefficient of variation in percent.

\subsection{Marketable Tuber Yield}

With respect to the marketable tuber yield, statistically significant differences of different level of significance were revealed among potato cultivars under evaluation and a check (Bubu). The highest tuber yield was apprehended with cultivar Bubu $\left(34.79 \mathrm{t} \mathrm{ha}^{-1}\right)$ and Gebissa $\left(33.485 \mathrm{t} \mathrm{ha}^{-1}\right)$ while the lowest with variety Jarso $\left(15.93 \mathrm{t} \mathrm{ha}^{-1}\right)$. The marketable tuber yield differences between varieties Gebisa (33.485 $\left.\mathrm{t} \mathrm{ha}^{-1}\right)$ and Gudene (31.275 $\left.\mathrm{t} \mathrm{ha}^{-1}\right)$ comparing with standard check $\left(34.79 \mathrm{t} \mathrm{ha}^{-1}\right)$, were showed statistically no difference. Statistically highly significant differences were shown with respect to the cultivars planted in different seasons comparing with standard check (Bubu). The highest marketable tuber yield was obtained with potato cultivars planted in 2018 crop growing season, Gebissa $\left(38.22 \mathrm{t} \mathrm{ha}^{-1}\right)$ comparing with those planted in 2017, Bubu (31.66 t $\mathrm{ha}^{-1}$ ) (Table 4).

Table 4. Comparison of eight potato cultivars on marketable and total tuber yield

\begin{tabular}{|c|c|c|c|c|c|c|}
\hline \multirow{2}{*}{ Treatment } & \multicolumn{3}{|c|}{ Marketable tuber $\left(\mathrm{t} \mathrm{ha}^{-1}\right)$} & \multicolumn{3}{|c|}{ Total yield $\left(\mathrm{t} \mathrm{ha}^{-1}\right)$} \\
\hline & 2017 & 2018 & Average & 2017 & 2018 & Average \\
\hline Bubu & $31.66^{\mathrm{a}}$ & $37.92^{\mathrm{a}}$ & $34.79^{\mathrm{A}}$ & $35.16^{\mathrm{a}}$ & $43.63^{\mathrm{a}}$ & $39.395^{\mathrm{A}}$ \\
\hline Chiro & $22.22^{\mathrm{cd}}$ & $28.44^{\mathrm{bc}}$ & $25.33^{\mathrm{C}}$ & $26.53^{\mathrm{de}}$ & $31.66^{\mathrm{b}-\mathrm{e}}$ & $29.095^{\mathrm{DE}}$ \\
\hline Gebisa & $28.75^{\mathrm{a}-\mathrm{c}}$ & $38.22^{\mathrm{a}}$ & $33.485^{\mathrm{A}}$ & $32.73^{\mathrm{a}-\mathrm{d}}$ & $42.59^{\mathrm{a}}$ & $37.66^{\mathrm{AB}}$ \\
\hline Jarso & $12.6^{\mathrm{f}}$ & $19.26^{\mathrm{d}}$ & $15.93^{\mathrm{E}}$ & $17.53^{\mathrm{g}}$ & $24.25^{\mathrm{de}}$ & $20.89^{\mathrm{G}}$ \\
\hline Belete & $22.41^{\mathrm{cd}}$ & $23.57^{\mathrm{cd}}$ & $22.99^{\mathrm{CD}}$ & $28.33^{\mathrm{c}-\mathrm{e}}$ & $30.91^{\mathrm{c}-\mathrm{e}}$ & $29.62^{\mathrm{C}-\mathrm{E}}$ \\
\hline Gudene & $29.07^{\mathrm{a}-\mathrm{c}}$ & $33.48^{\mathrm{ab}}$ & $31.275^{\mathrm{AB}}$ & $34.06^{\mathrm{a}-\mathrm{c}}$ & $36.33^{\mathrm{a}-\mathrm{c}}$ & $35.195^{\mathrm{A}-\mathrm{C}}$ \\
\hline Badasa & $20.93^{\mathrm{de}}$ & $28.44^{\mathrm{bc}}$ & $24.685^{\mathrm{CD}}$ & $28.46^{\mathrm{c}-\mathrm{e}}$ & $30.61^{\mathrm{c}-\mathrm{e}}$ & $29.535^{\mathrm{C}-\mathrm{E}}$ \\
\hline Dedafa & $19.48^{\mathrm{d}-\mathrm{f}}$ & $17.74^{\mathrm{d}}$ & $18.61^{\mathrm{DE}}$ & $24.29^{\mathrm{ef}}$ & $21.84^{\mathrm{e}}$ & $23.065^{\mathrm{FG}}$ \\
\hline $\operatorname{LSD}(5 \%)$ & 6.899 & 9.029 & 5.755 & 6.645 & 10.253 & 5.902 \\
\hline $\mathrm{CV}$ & 17.5 & 19.8 & 13.5 & 13.6 & 19.2 & 11.6 \\
\hline $\mathrm{T}$ test & $*$ & $*$ & $*$ & $*$ & $*$ & $*$ \\
\hline
\end{tabular}

Note. Means with the same letter(s) within a column are not significantly different at $5 \%$ level of significance. $\mathrm{NS}=$ non-significant difference, $\operatorname{LSD}(5 \%)=$ Least significant difference at $\mathrm{P}=0.05$, and CV $(\%)=$ Coefficient of variation in percent.

\subsection{Tuber Yield}

With respect to the tuber yield, statistically significant differences of different level of significance were found among potato cultivars under evaluation and standard check (Bubu). The highest tuber yield was revealed with 
cultivar Bubu (39.395 $\mathrm{t} \mathrm{ha}^{-1}$ ) while the lowest with variety Jarso $\left(20.89 \mathrm{t} \mathrm{ha}^{-1}\right)$. The yield differences between varieties Gebisa (37.66 t ha ${ }^{-1}$ ) and Gudene (35.195 $\mathrm{t} \mathrm{ha}^{-1}$ ) comparing with standard check $\left(39.395 \mathrm{t} \mathrm{ha}^{-1}\right)$, were showed statistically no difference. Statistically highly significant differences were shown with respect to the potato cultivars planted in different seasons comparing with standard check (Bubu). The highest tuber yield was obtained with cultivars planted in 2018 crop growing season (43.63 $\mathrm{t} \mathrm{ha}^{-1}$ ) comparing with those planted in 2017 (35.16 $\left.\mathrm{t} \mathrm{ha}^{-1}\right)$ (Table 4).

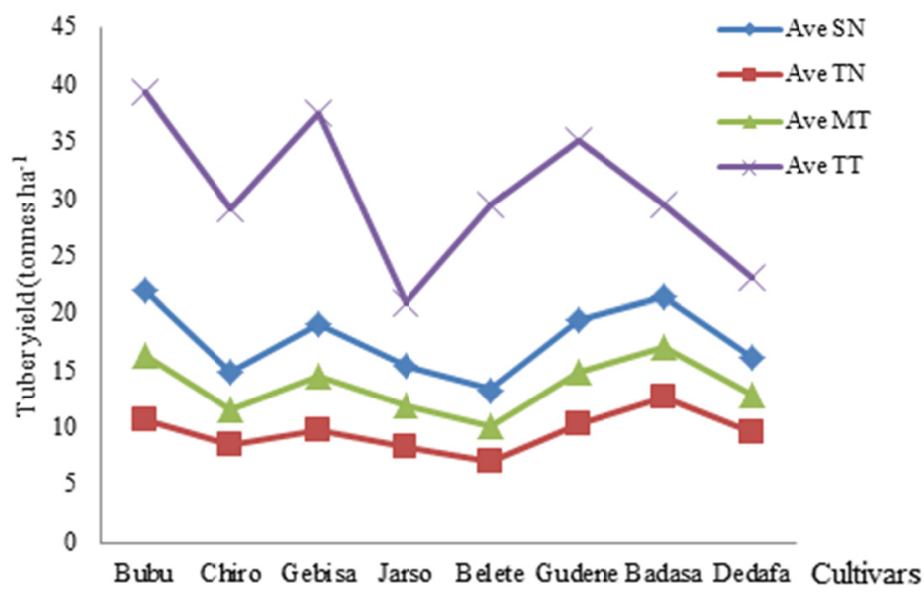

Figure 2. The correlation between average stolon number (Ave SN), average tuber number (Ave TN), average marketable tuber yield (Ave MT), and average total tuber yield (Ave TT) during 2017 and 2018 potato growing season

There were high correlation between average stolon number and tuber number (0.915522), stolon number and marketable tuber yield (0.989494), stolon number and average total tuber yield (0.629363), average tuber number and marketable tuber yield (0.964061), average marketable yield and total tuber yield (0.54619). There was no correlation between average tuber number and total tuber yield $(0.36317)$.

\section{Discussions}

The results showed that potato tuber seed performed differently on growth and yield to different potato cultivars. These differences between seasons to some extent were predicted, putting in consideration to different climatic and pedologic conditions (soil erosion, percolation, drainage and etc.) that were existent in both seasons, with more suitable for potato farming in 2018 crop growing season. Lack of quality seed potato and high yielding varieties with poor agricultural management was the key factor for low yield of potato (Amede et al., 2006). The obtained results also revealed that improved potato varieties showed highest total tuber yield over the local varieties. Maximum advantages of growing improved potato variety are the packages of production were tagged during the registration of the variety while the treatment of local potato variety is determined by farmers themselves. Significant difference for grade wise tuber yield was found among different genotypes (Bhardwaj et al., 2008) and different treatments (Banjare et al., 2014; Chilephake \& Trautz, 2014) while non-significant difference was also found by Banjare et al. (2014). Among other horticultural crops, the potato is one of the most demanded on the market in eastern Ethiopia. High yield potato production depends on growing conditions, nutritional support, pest control, especially late blight. Bubu potato variety which was used a standard check is resistant to late while Gudene variety is tolerant to this disease.

Most of the potato genotypes that have been released in Ethiopia before 2008 were either with major genes for vertical resistance or were developed for horizontal resistance against the disease in the presence of unknown resistance major R genes (Gebremedhin, 2013), which were named population A clones (Landeo et al., 1997). One reason why Bubu and Gebissa produced high tuber yield was their resistance and tolerance to late blight potato disease, respectively. This circumstance will partially overcome in conventional agriculture by fertilising and spraying pesticides for other varieties which are susceptible to late blight disease. Flexible and robust varieties are required for such specific higher yield potato growing conditions. The evaluation of potato varieties in different growing seasons and at similar field determined the most important traits for high yield potato production. The most important trait is resistance to different pathogens (late blight, black scurf, virus diseases, rhizoctonia etc.), (Zimnoch-Guzovska, 2003; Tiemens-Hulscher et al., 2003). The desired traits for potato 
breeding are adaptability to organic fertilization (adequate root system, rapid juvenal root and plant development, good growth vigour, efficient mineral uptake and use), the ability to produce a good yield in a short growing period (early bulking and ripening, yield stability, acceptable quality, good storability) (Tiemens-Hulscher et al., 2003) and meeting market needs. The selection in the high tuber yield potato variety will include emphasis on rapid establishment, good ground cover, early bulking yield potential and tolerance to changeable humidity and fertility conditions through the better root system and resistance to late blight disease.

\section{Conclusions}

According to the ANOVA statistically significant differences of different level of significance were obtained among potato cultivars under evaluation and standard check (Bubu), with respect to the tuber yields, tuber number, etc. The highest tuber yield was revealed with cultivar Bubu $\left(39.395 \mathrm{t} \mathrm{ha}^{-1}\right)$ while the lowest with variety Jarso $\left(20.89 \mathrm{t} \mathrm{ha}^{-1}\right)$, whereas the highest number of tuber being to variety Badasa $\left(12.7315 \mathrm{plant}^{-1}\right)$ and the lowest one to variety Belete $\left(6.985\right.$ plant $\left.^{-1}\right)$. Average potato tuber yield in Ethiopia is low and not in synchronization with possibilities, thus the potato cultivars under these evaluations contributes good indication and opportunities for in country potato growers and processors to use some of these cultivars in order to achieve better yield and quality that will sustain their livelihood, significantly increase their profit and income generation. From the results of the current study it can be concluded that use of improved potato variety with recommended package of production is advised for potato growers in Eastern Ethiopia to sustain their life and increase the income by selling this crop.

\section{References}

Amede, T., German, L., Rao, S., Opondo, C., \& Stroud, A. (2006). Integrated natural resource management in practice: Enabling communities to improve mountain livelihoods and landscapes. Proceedings of the African Highland Initiative Conference (pp. 12-15).

Balkaya, A., \& Ergün, A. (2008). Diversity and use of pinto bean (Phaseolus vulgaris) populations from Samsun, Turkey. New Zealand Journal of Crop and Horticultural Science, 36(3), 189-197. https://doi.org/10.1080/ 01140670809510235

Banjare, S., Sharma, G., \& Verma, S. K. (2014). Potato crop growth and yield response to different levels of nitrogen under Chhattisgarh plains agro-climatic zone. Indian Journal of Science and Technology, 7(10), 1504-1508.

Bhardwaj, V., Pandey, S. K., Manivel, P., Singh, S. V., \& Kumar, D. (2008). Stability of indigenous and exotic potato processing cultivars in Himachal Pradesh hills. Proceedings of the Global Potato Conference (pp. 9-12).

Gildemacher, P. R., Demo, P., Barker, I., Kaguongo, W., Woldegiorgis, G., Wagoire, W. W., \& Struik, P. C. (2009). A description of seed potato systems in Kenya, Uganda and Ethiopia. American Journal of Potato Research, 86(5), 373-382. https://doi.org/10.1007/s12230-009-9092-0

Hirpa, A., Meuwissen, M. P., Tesfaye, A., Lommen, W. J., Lansink, A. O., Tsegaye, A., \& Struik, P. C. (2010). Analysis of seed potato systems in Ethiopia. American Journal of Potato Research, 87(6), 537-552. https://doi.org/10.1007/s12230-010-9164-1

Landeo, J. A., Gastelo, M., Forbes, G., Zapata, J. L., \& Flores, F. J. (1997). Developing horizontal resistance to late blight in potato. Working Paper (CIP).

Lung'aho, C., Lemaga, B., Nyongesa, M., Gildermacher, P., Kinyale, P., Demo, P., \& Kabira, J. (2007). Commercial seed potato production in eastern and central Africa (p. 140). Kenya Agric. Inst.

MoA (Ministry of Agriculture). (2012). Crop Variety Register (Issue No. 15, pp. 37-38). Animal and Plant Health Regulatory Directorate, Addis Ababa, Ethiopia.

MoA (Ministry of Agriculture). (2013). Crop Variety Register (Issue No. 16, pp. 161-164). Plant Variety Release, Protection and Seed Quality Control Directorate, Addis Abeba, Ethiopia.

Schliephake, U., \& Trautz, D. (2014). Tuber development rates of six potato varieties in organic farming in Osnabrück, Germany. Building Organic Bridges, 2, 383-386.

Tiemens-Hulscher M., Hospers M., Burgt G., Bergt C., Bremmer E., \& Lammerts van Bueren E. (2003). Towards an organic potato ideotype. Breeding and Adaptation of Potatoes (p. 7). EAPR, EUCARPIA. 
Vleeshouwers, V. G., Raffaele, S., Vossen, J. H., Champouret, N., Oliva, R., Segretin, M. E., ... Pel, M. A. (2011). Understanding and exploiting late blight resistance in the age of effectors. Annual Review of Phytopathology, 49, 507-531. https://doi.org/10.1146/annurev-phyto-072910-095326

Woldegiorgis, G. (2008a). Introductory remark. In G. Woldegiorgis, E. Gebre, \& B. Lemaga (Eds.), Root and tuber crops: The untapped resources. Ethiopian Institute of Agricultural Research (EIAR).

Woldegiorgis, G. 2013. Potato variety development strategies and methodologies in Ethiopia. In G. Woldegiorgis, S. Schulz, \& B. Baye (Eds.), Seed potato tuber production and disseminations, experiences, challenges and prospects (pp.45-59). Proceedings of the National Workshop on Seed Potato Tuber Production and Dissemination, Ethiopian Institute of Agricultural Research and Amhara Region Agriculture Research Institute, Mach 12-14, 2012, Bahir Dar, Ethiopia.

Zimnoch-Guzovska, E. (2003) Demand for low input varieties. Breeding and adaptation of potatoes (p. 1). EAPR, EUCARPIA.

\section{Copyrights}

Copyright for this article is retained by the author(s), with first publication rights granted to the journal.

This is an open-access article distributed under the terms and conditions of the Creative Commons Attribution license (http://creativecommons.org/licenses/by/4.0/). 